\title{
Emerging Viral and Bacterial Infections: Within an Era of Opioid Epidemic
}

Jessica F. Jones (D) - Jamie Legaspi • Eric Chen · Kelly Lee •

Jennifer Le (D)

Received: June 29, 2020 / Published online: September 11, 2020

(c) The Author(s) 2020

\section{ABSTRACT}

The opioid epidemic is a public health crisis that continues to impact healthcare in the United States of America (USA). While changes in opioid prescribing have curbed the medical use of opioids, the increase in nonmedical use, largely driven by injection drug use (IDU), has contributed to the escalating incidence of opioid use disorder (OUD). Furthermore, IDU is associated with high-risk injection practices that can increase the risk of acquiring viral and bacterial infections. Here in this comprehensive review, we aimed to summarize the epidemiology and management of OUD, along with the screening and antimicrobial treatment of associated infections, specifically focused on human immunodeficiency virus, hepatitis $C$ virus, skin and soft tissue infections, endocarditis, and osteomyelitis. Medication-assisted therapy (MAT) and infection guidelines from the USA will be presented.

Digital Features To view digital features for this article go to https://doi.org/10.6084/m9.figshare.12855173.

J. F. Jones $(\bowtie) \cdot J$. Legaspi · E. Chen

University of California San Diego Health, San

Diego, CA, USA

e-mail: jfjones@health.ucsd.edu

K. Lee $\cdot$ J. Le

Skaggs School of Pharmacy and Pharmaceutical Sciences, University of California San Diego, La Jolla, San Diego, CA, USA
Keywords: Bacterial infection; Hepatitis C; Opioid use disorder; Viral infection

\section{Key Summary Points}

Opioid use disorder is a growing problem in the USA.

Opioid use disorder can lead to injection drug use and substance abuse.

Injection drug use is comorbid with viral infections such as hepatitis $\mathrm{C}$ and human immunodeficiency virus as well as bacterial infections.

Healthcare providers play a vital role in early detection of opioid use disorder and thus resources should be available to educate providers and patients.

\section{DIGITAL FEATURES}

This article is published with digital features to facilitate understanding of the article. You can access the digital features on the article's associated Figshare page. To view digital features for this article go to https://doi.org/10.6084/m9. figshare.12855173. 


\section{EPIDEMIOLOGY}

The opioid epidemic is a growing problem that has increased mortality and hospitalization since its emergence. In 2017, the US Department of Health and Human Services (HHS) declared the opioid epidemic as a public health emergency. In 2018, the United Nations Office on Drugs and Crime (UNODC) launched a strategic response to combat the epidemic. The opioid epidemic began in the 1990s in the USA, marked by increased prescribing of opioids and methadone for the management of acute and chronic pain relief. Prescriptions for opioids increased significantly from 180 morphine milligram equivalents (MME) per capita in 1999 to a peak of $782 \mathrm{MME}$ per capita in 2010 [1]. Prescribing rates stayed constant between 2010 and 2012, and then began to decline. In 2015, the USA rate of opioid prescribing decreased $20 \%$ to $640 \mathrm{MME}$ per capita [2]. Despite the decline in opioid prescribing rates, the rate in 2015 was three times higher than the reported rate in 1999. The extensive medical prescribing of opioids from 1990 into the early 2000s led to widespread community use and dependence. As prescribing standards became more stringent and regulated, patients increasingly began to seek opioids from illegal sources. These unregulated sources of opioids are now a factor in the increasing death rate from opioid overdoses and are a major contributor to the opioid use disorder (OUD) we encounter today [3]. This article is based on previously conducted studies and does not contain any studies with human participants or animals performed by any of the authors.

\section{OPIOID USE DISORDER}

The opioid epidemic gave rise to the increasing incidence of OUD, which is a chronic lifelong disorder with potentially significant health consequences including disability, relapse, and death [4]. Opioids that have contributed to the emerging epidemic include prescription-based (i.e., fentanyl and oral pain relievers such as oxycodone and hydrocodone) and heroin. The American Psychiatric Association DSM-5 criteria define OUD as a problematic pattern of opioid use, including tolerance, impaired occupation/social function, craving, or continued dependence despite worsening psychological distress or withdrawal, within a period of 12 months. Mechanistically, opioids activate the mu-opioid receptor to reduce the perception of pain but can also activate the mesolimbic (midbrain) reward system [5]. The reward system in the ventral tegmental area releases dopamine in the nucleus accumbens, eliciting feelings of pleasure and euphoria. As a result, chronic use of opioids leads to conditioned associations and positive reinforcement of this euphoric state, thus increasing the risk for OUD despite the potential for negative consequences $[4,5]$.

Despite the availability of effective opioid treatment programs, there are still many deaths related to opioid overdoses in the USA. In 2018, nearly $70 \%$ of 67,367 deaths due to drug overdoses involved an opioid [3]. On average, the overdose death rate increased by $10 \%$ per year from 1999 through 2006, by 2\% per year from 2006 through 2013, and by $14 \%$ per year from 2013 through 2016 [6]. The age-adjusted rate of drug overdose deaths involving synthetic opioids such as fentanyl, fentanyl analogues, and tramadol, increased by $188 \%$ from 0.3 per 100,000 standard population in 1999 to 1.0 in 2013, and 9.9 in 2018 [6, 7].

Currently, the Centers for Disease Control and Prevention (CDC) attributes illicit synthetic opioids as the driver of drug overdose death in the USA [8-11]. In fact, fentanyl, first approved by the Food and Drug Administration (FDA) in 1998 to treat breakthrough cancer pain, is 50-100 times more potent than morphine and can be produced in illegal laboratories [12]. Illegally produced fentanyl is often cheaper and easier to obtain than heroin or prescription fentanyl. Illicit fentanyl can be used as an additive to heroin, cocaine, or other counterfeit pills, which makes uninformed users more susceptible to addiction and overdose [13].

As people with OUD shift from prescription opioids to cheaper street alternatives, the use of heroin has also increased within the USA. In 2010, approximately 600,000 people reporting 
Table 1 Medication-assisted treatment (MAT) for opioid use disorder (OUD)

\begin{tabular}{|c|c|c|c|}
\hline Medication & Mechanism of action & Dose and recommendations & Treatment considerations \\
\hline Buprenorphine & $\begin{array}{l}\text { Mixed agonist/antagonist: } \\
\text { partial mu-opioid receptor } \\
\text { agonist and kappa-opioid } \\
\text { receptor antagonist }\end{array}$ & $\begin{array}{l}\text { Individualize on the basis of } \\
\text { patient's opioid use } \\
\text { Usual dose range: } 4-24 \mathrm{mg} \\
\text { sublingually once or twice daily }\end{array}$ & $\begin{array}{l}\text { Potential interactions with CYP } \\
\text { inhibitors or inducers } \\
\text { Available co-formulations with } \\
\text { naloxone } \\
\text { Must educate the patient on } \\
\text { appropriate administration } \\
\text { technique, especially for sublingual } \\
\text { administration }\end{array}$ \\
\hline Methadone & $\begin{array}{l}\text { Agonist at the mu-opioid } \\
\text { receptor and antagonist at } \\
\text { the } N \text {-methyl-D-aspartate } \\
\text { (NMDA) receptor }\end{array}$ & $\begin{array}{l}\text { Individualize dose. Patients who } \\
\text { receive higher doses }(>100 \mathrm{mg}) \\
\text { are more likely to remain } \\
\text { compliant with treatment }\end{array}$ & $\begin{array}{l}\text { Potential interactions with CYP } \\
\text { inhibitors or inducers } \\
\text { QTc prolongation is a concern at } \\
\text { higher doses } \\
\text { Can only be prescribed for OUD by } \\
\text { a licensed opioid treatment } \\
\text { program }\end{array}$ \\
\hline Naltrexone & Antagonist at opioid receptor & $\begin{array}{l}\text { 50-100 mg by mouth once daily } \\
\text { Depot formulation: fixed-dose } \\
\text { monthly injection }\end{array}$ & $\begin{array}{l}\text { No significant interactions } \\
\text { Longer time of continuous } \\
\text { abstinence in those who received } \\
\text { depot formulation compared to } \\
\text { placebo after transition from } \\
\text { prison to community }\end{array}$ \\
\hline
\end{tabular}

Adapted from treatment options for opioid use disorder within HIV guidelines [28]

heroin use compared with 400,000 people in 2002 [14]. The increase in heroin use has also contributed to the overall increase in overdoserelated deaths, already reported with prescription opioids. In 2018, nearly 15,000 people died from a drug overdose involving heroin in the USA, a rate of almost five deaths for every 100,000 Americans [15]. Furthermore, the association of oral opioid misuse and injection heroin use is also escalating [16-18], as many individuals transition from oral opioids to injectable heroin due to its increased potency $[16,19,20]$. The increase of injection drug use (IDU) within the opioid epidemic drives a surge in both viral and bacterial infections, including human immunodeficiency virus (HIV) infection, viral hepatitis, infective endocarditis, and skin and soft tissue infections [21, 22].

\section{MEDICATION-ASSISTED THERAPY (MAT)}

MAT is a major component of OUD treatment programs. Treatment options for MAT are provided in Table 1 . All three medications target the central mu-opioid receptor for therapeutic activity; however, they differ slightly in their pharmacokinetic and pharmacodynamic properties. All three medications are useful in treating the physiological dependence associated with OUD; however, the addition of an opioid antagonist in maintenance therapy doubles 
Table 2 Epidemiology, risk factors, and antimicrobial treatment of infections associated with injection drug use

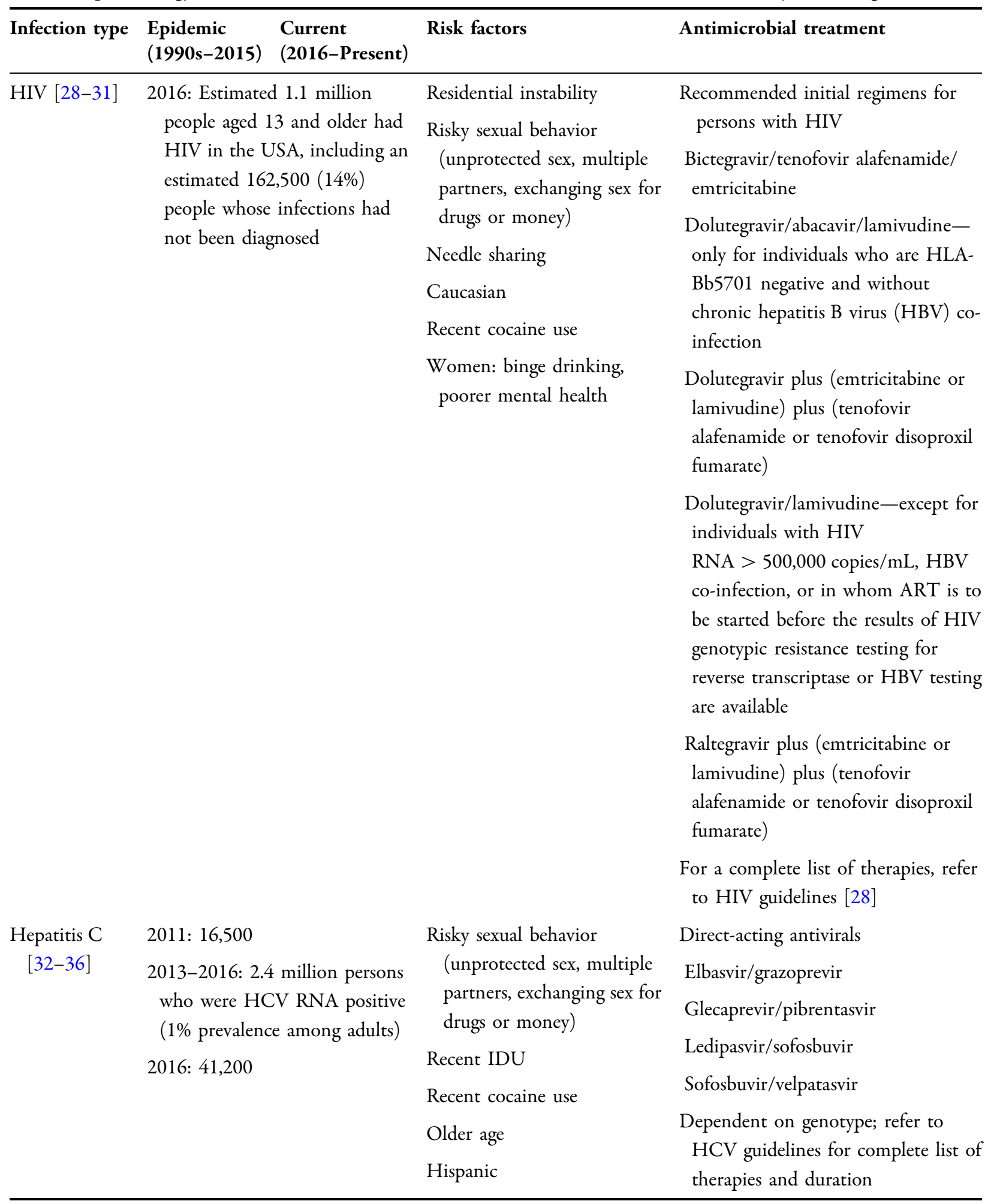


Table 2 continued

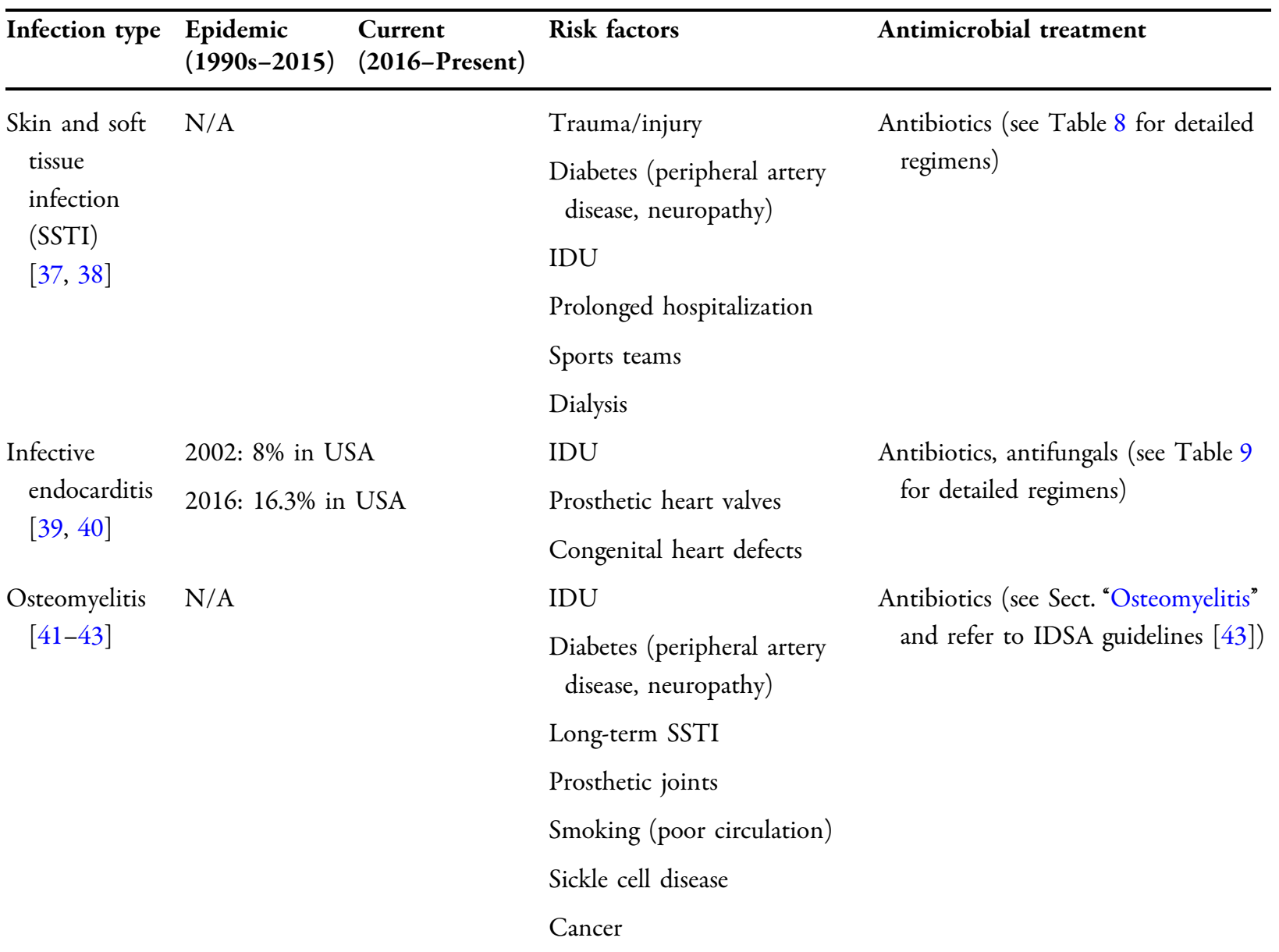

opioid abstinence success rate compared to treatments without opioid antagonists [23]. The use of oral naltrexone without combination opioid agonist is FDA approved to treat OUD; however, it is often excluded from consideration because of poor adherence and poor outcomes in clinical studies [24]. In addition to pharmacologic support, OUD treatment programs use social support and counseling to help decrease opioid cravings.

Outcomes for MAT in among persons who inject drugs (PWID) are promising. Of PWID diagnosed with HIV and concomitantly on MAT, there was a $69 \%$ increase in recruitment onto antiretroviral therapy (ART), 54\% increase in ART coverage, a twofold increase in adherence, and $23 \%$ decrease in the odds of attrition compared to those not on MAT [25]. Other harm reduction strategies include overdose education, safe injections spaces and sterile needle programs. Syringe service programs provide IDUs with sterile syringes and other equipment to reduce the risk of HIV and hepatitis $\mathrm{C}$ virus (HCV) transmission. A prospective study in New York City found that HIV prevalence declined from $80 \%$ to $59 \%$ and HCV rates declined from $90 \%$ to $63 \%$ from 1990 to 2001 in PWID. These corresponded to an increase in the number of syringes distributed by these programs, ranging from 250,000 to 3,000,000 syringes exchanged annually [26]. In addition, MAT has been proven to improve social outcomes for parents with OUD with lower incidence of child mistreatment and introduction into the fostercare system [27] (Table 2). 


\section{VIRAL INFECTIONS}

The augmented use of IDU within the opioid epidemic has led to an increase in viral infections, such as HIV and hepatitis $\mathrm{C}$ virus (HCV). $\mathrm{HIV}$ and $\mathrm{HCV}$ infections are transmitted between individuals through high-risk injection practices, such as sharing syringes, drug paraphernalia, and high dead-space syringes [44]. Another mode of transmission is unprotected sex, in which one study reported its increase in individuals using non-medical prescription opioids [45]. The management of HIV and HCV infections in PWID should focus on treatment, continual monitoring, adherence, and harm reduction. The sections that follow address the management of these viral infections.

\section{Human Immunodeficiency Virus}

In 2016, injection opioid use was responsible for $13 \%$ of new HIV diagnoses and linked to localized outbreaks in Scott County, Indiana and Lawrence and Lowell, Massachusetts [44]. PWID accounted for 9\% $(3641 / 38,739)$ of new HIV diagnoses in the USA in 2017 [46]. Although other factors, such as ART coverage, have increased from 58\% to $71 \%$ between 2009 and 2015 among people with HIV who also engaged in IDU [47], patients still face social and economic barriers that limit access to HIV prevention and treatment services. One study found that more than half $(56 \%)$ of PWID reported being homeless, $25 \%$ reported being incarcerated, and $16 \%$ reported having no health insurance in the preceding 12 months [46].

The US HHS Guidelines for the Use of Antiretroviral Agents in Adults and Adolescents with HIV do not have a specific section dedicated to PWID, but recognize the presence of substance use disorders (SUD) among people with HIV [28]. Unaddressed SUD may prevent an individual from being tested for HIV, initiating ART, or adhering to ART. Furthermore, unaddressed SUD can increase behaviors that place a person at risk for HIV transmission; therefore, it is critical to address SUD to mitigate potential barriers to treatment [28]. Key considerations and recommendations for managing
HIV patients with SUD are summarized in Table 3. Generally, ART regimens should be simplified to maximize adherence. If possible, patients should receive once-daily, single-tablet regimens with a high barrier to developing resistance and a low risk of hepatotoxicity [48].

Ideal ART regimens combine high efficacy, high tolerability, low toxicity, low pill burden, affordability and availability. The HIV guidelines list the following regimens as recommended initial regimens for most people with HIV:

- Bictegravir/tenofovir alafenamide/emtricitabine

- Dolutegravir/abacavir/lamivudine-only for individuals who are HLA-Bb5701 negative and without chronic hepatitis B virus (HBV) co-infection

- Dolutegravir plus (emtricitabine or lamivudine) plus (tenofovir alafenamide or tenofovir disoproxil fumarate)

- Dolutegravir/lamivudine-except for individuals with HIV RNA $>500,000$ copies/ $\mathrm{mL}, \mathrm{HBV}$ co-infection, or in whom ART is to be started before the results of HIV genotypic resistance testing for reverse transcriptase or HBV testing are available

- Raltegravir plus (emtricitabine or lamivudine) plus (tenofovir alafenamide or tenofovir disoproxil fumarate)

Table 4 lists potential ART regimens with respect to patient-specific factors and clinical scenario considerations.

In patients with SUD, the HIV guidelines recommend evidence-based pharmacotherapy according to specific substance use disorder, including alcohol and nicotine (Table 5). Alcohol consumption in HIV is estimated to be greater than $50 \%$, with a range of $54-67 \%$ $[49,50]$. Unhealthy alcohol use can increase the frequency of risky behaviors associated with sexual transmission of HIV and has been linked to HIV acquisition [28]. In addition, unhealthy alcohol use has also been associated with lower adherence to ART [28]. Ongoing alcohol use is not a contraindication to receive ART; however, addressing alcohol use may improve treatment outcomes [51]. FDA-approved pharmacotherapies can also be prescribed for alcohol use disorder (Table 5). 
Table 3 Key considerations and recommendations for patients with SUD disorders and HIV [28]

Substance use disorders (SUDs) are prevalent among people with HIV and contribute to poor health outcomes; therefore, screening for SUDs should be a routine part of clinical care

Healthcare providers should be nonjudgmental when addressing substance use with their patients

Persons with HIV and SUDs should be screened for additional mental health disorders

Persons with HIV and SUDs should be offered evidenced-based pharmacotherapy (e.g., opioid agonist therapy, tobacco cessation treatment, alcohol use disorder treatment) as part of comprehensive HIV care in HIV clinical settings

Ongoing substance use is not a contraindication to antiretroviral therapy (ART). Persons who use substances can achieve and maintain viral suppression with ART

Substance use may increase the likelihood of risk-taking behaviors (e.g., risky sexual behaviors), the potential for drug-drug interactions, and the risk or severity of substance-associated toxicities (e.g., increased hepatotoxicity or an increased risk of overdose)

Selection of ART regimens for individuals who practice unhealthy substance and alcohol use should take potential adherence barriers, comorbidities which could impact care (e.g., advanced liver disease from alcohol or hepatitis viruses), potential drug-drug interactions, and possible adverse events associated with the medications into account

ART regimens containing once-daily dosing of singletablet regimens with high barriers to resistance, low potential for hepatotoxicity, and low potential for drug-drug interactions are preferred

The prevalence of tobacco smoking among persons with HIV in the USA is approximately $33.6 \%$ versus $16.8 \%$ in the general population [28]. Among 17,995 HIV-infected individuals on ART in Europe and North America, individuals who smoked had nearly twice the mortality of those who did not (mortality rate ratio 1.94; 95\% CI 1.56-2.41), with significant mortality attributed to cardiovascular disease and nonAIDS-related malignancy at increasing age [52]. Therefore, cessation of tobacco can lead to improved quality of life in these individuals. Clinicians should consider using behavioral and pharmacological approaches when treating patients with HIV who use tobacco. These include, but are not limited to, advising the patient to quit smoking, using the five A's (Ask, Advise, Assess, Assist, and Arrange), motivational interviewing, and referring the patient to a tobacco quitline [28]. Pharmacotherapies for smoking cessation are described in Table 5.

The guidelines emphasize that while treatment for an OUD can improve HIV treatment outcomes, it is not a prerequisite for treating HIV. Data from the Johns Hopkins HIV Clinical Cohort (2001-2012) demonstrated that in the early years of the cohort, people with IDU were less likely to be retained in care [53]. In addition, people with IDU and non-injection drug users (non-IDU) had similar probabilities of being on ART and having a suppressed viral load during the later years of the cohort. In 2001, $68.4 \%$ of PWID were retained in care, $45.5 \%$ on ART, and $28.0 \%$ virally suppressed, compared to $79.4 \%, 62.4 \%$, and $41.7 \%$ of non-IDU, respectively. However, these gaps closed by 2010 . In $2012,82.2 \%$ of PWID were retained in care, $76.3 \%$ on ART, and $69.1 \%$ virally suppressed, compared to $80.9 \%, 77.1 \%$, and $71.0 \%$ of nonIDU, respectively, demonstrating that patients are able to successfully adhere to ART despite ongoing opioid use [53].

The closed gap can be attributed to multiple interventions as previously referenced including MAT, syringe service programs, and overdose education and naloxone distribution. For PWID, sharing needles and syringes is a major route of transmission for HIV, and needle and syringe programs (NSPs) are considered a key component of management of PWID [54]. NSPs are community-based programs that provide access to sterile needles and syringes, facilitate safe disposal of used syringes, and provide or link to other services such as MAT and naloxone distribution and education [55]. A meta-analysis of 13 systematic reviews found that NSPs were 
Table 4 Recommended ART regimens based on selected patient-specific factors and clinical scenarios [28]

\begin{tabular}{|c|c|c|}
\hline Clinical scenario & Medication & Dose \\
\hline \multirow[t]{10}{*}{ Single-tablet regimen options for initial therapy } & $\begin{array}{l}\mathrm{BIC} / \mathrm{TAF} / \\
\mathrm{FTC}\end{array}$ & 1 tablet once daily \\
\hline & $\begin{array}{l}\mathrm{DOR} / \mathrm{TDF} / \\
3 \mathrm{TC}\end{array}$ & 1 tablet once daily \\
\hline & $\begin{array}{l}\mathrm{DRV} / \mathrm{c} / \mathrm{TAF} / \\
\mathrm{FTC}\end{array}$ & 1 tablet once daily with food \\
\hline & $\begin{array}{l}\mathrm{DTG} / \mathrm{ABC} / \\
\text { 3TC }\end{array}$ & 1 tablet once daily \\
\hline & DTG/3TC & 1 tablet once daily \\
\hline & $\begin{array}{l}\mathrm{EFV} / \mathrm{TDF} / \\
\mathrm{FTC}\end{array}$ & $\begin{array}{l}1 \text { tablet once daily on an empty stomach, preferably at } \\
\text { bedtime }\end{array}$ \\
\hline & $\begin{array}{l}\mathrm{EVG} / \mathrm{c} / \mathrm{TAF} / \\
\mathrm{FTC}\end{array}$ & 1 tablet once daily with food \\
\hline & $\begin{array}{l}\mathrm{EVG} / \mathrm{c} / \mathrm{TDF} / \\
\mathrm{FTC}\end{array}$ & 1 tablet once daily with food \\
\hline & $\begin{array}{l}\mathrm{RPV} / \mathrm{TAF} / \\
\mathrm{FTC}\end{array}$ & 1 tablet once daily with a meal \\
\hline & $\begin{array}{l}\mathrm{RPV} / \mathrm{TDF} / \\
\mathrm{FTC}\end{array}$ & 1 tablet once daily \\
\hline \multirow[t]{2}{*}{ High barrier to resistance } & $\mathrm{BIC}$ & \\
\hline & DTG & \\
\hline \multirow[t]{5}{*}{ Potential for hepatotoxicity } & DTG & \\
\hline & ZDV & \\
\hline & $\mathrm{RPV}$ & \\
\hline & DRV & \\
\hline & MVC & \\
\hline \multirow[t]{2}{*}{ Drug-drug interactions } & \multicolumn{2}{|c|}{ Least: integrase inhibitors (BIC, DTG, RAL) } \\
\hline & \multicolumn{2}{|c|}{ Most: pharmacokinetic boosters (COBI, RTV) } \\
\hline $\begin{array}{l}\text { On medication-assisted treatment for opioid use } \\
\text { disorder }\end{array}$ & \multicolumn{2}{|c|}{$\begin{array}{l}\text { Opioid withdrawal may occur when EFV is initiated in patients who are } \\
\text { on a stable dose of methadone. Clinical monitoring recommended }\end{array}$} \\
\hline
\end{tabular}

$3 T C$ lamivudine, $A B C$ abacavir, $B I C$ bictegravir, $C O B I$ cobicistat, $D O R$ doravirine, $D R V$ darunavir, $D R V / c$ darunavir/cobicistat, $D T G$ dolutegravir, $E F V$ efavirenz, $E V G$ elvitegravir, $E V G / c$ elvitegravir/cobicistat, $F T C$ emtricitabine, $M V C$ maraviroc, $R A L$ raltegravir, $R P V$ rilpivirine, $R T V$ ritonavir, $T A F$ tenofovir alafenamide, $T D F$ tenofovir disoproxil fumarate, $Z D V$ zidovudine 
Table 5 Medications for treatment of substance use disorders [28]

\begin{tabular}{llll}
\hline Medication & Dose and recommendations & $\begin{array}{l}\text { Potential interactions with } \\
\text { ART }\end{array}$ & Comments \\
& & \\
\hline
\end{tabular}

Alcohol use disorder

Acamprosate $666 \mathrm{mg}$ PO three times a day

Or

$333 \mathrm{mg}$ PO three times a day for patients with creatinine clearance $(\mathrm{CrCl}) 30-50 \mathrm{~mL} /$ $\min$

Disulfiram $250 \mathrm{mg}$ PO once daily

Naltrexone

50-100 mg PO once daily depot formulation is a fixed-dose monthly injection

Nicotine use disorder

Nicotine There are a wide variety of FDAreplacement therapy

Bupropion approved nicotine replacement products. All formulations are effective

Start at $150 \mathrm{mg}$ PO daily for 3 days, then increase to either $150 \mathrm{mg}$ twice daily or $300 \mathrm{mg}$ once daily (only use formulations that are approved for once-daily dosing)

Varenicline Titrate dose on basis of tolerability until desired effect is achieved. The goal is to reach a dose of $1 \mathrm{mg}$ PO twice daily

Requires dose adjustment in patients with $\mathrm{CrCl}<30 \mathrm{~mL}$ / $\min$
No significant interaction with ART drugs expected

Contraindicated in patients with $\mathrm{CrCl}<30 \mathrm{~mL} / \mathrm{min}$

$$
\begin{aligned}
& \text { Use with caution when } \\
& \text { prescribing an ART oral } \\
& \text { solution that contains ethanol } \\
& \text { and/or propylene glycol (e.g., } \\
& \text { fosamprenavir, lopinavir/ } \\
& \text { ritonavir, ritonavir) }
\end{aligned}
$$

No significant interaction with ART drugs expected

No significant interaction with ART drugs expected

Concentration may be reduced when used with ART drugs that are CYP2D6 inducers. Refer to guidelines for further recommendations

No significant interaction with ART drugs expected
Counsel patients regarding disulfiram reaction when taken with alcohol; symptoms for the reaction may include flushing, tachycardia, nausea, vomiting, or hypotension

Has the greatest efficacy of all FDA-approved medications for alcohol use disorder

Work with the patient to identify the route of delivery that the patient will use and find most helpful

Tobacco quit date should ideally be 1 week after starting therapy

Tobacco quit date should ideally be 1 week after starting therapy 
Table 6 Recommendations for screening and management of HCV infection in people with IDU [36]

Annual HCV testing is recommended for PWID with no prior testing, or past negative testing with subsequent IDU. Depending on the level of risk, more frequent testing may be indicated

Substance use disorder treatment programs and needle/ syringe exchange programs should offer routine, optout $\mathrm{HCV}$ antibody testing with reflexive or immediate confirmatory HCV-RNA testing and linkage to care for those who are infected

PWID should be counseled about measures to reduce the risk of $\mathrm{HCV}$ transmission to others

PWID should be offered harm reduction services, including intranasally administered naloxone, needle/ syringe service programs, medications for OUD, and other SUD treatment programs

Active or recent drug use or a concern for reinfection is not a contraindication to $\mathrm{HCV}$ treatment

At least annual HCV-RNA testing is recommended for PWID with recent IDU after they have spontaneously cleared HCV infection or have been successfully treated

effective in reducing HIV transmission among PWID [54]. Multiple studies have shown that effective NSPs significantly reduce the prevalence of HIV and person-years at risk for HIV in PWID $[56,57]$.

\section{Hepatitis C Virus}

The number of newly reported HCV diagnoses nearly tripled from 2010 to 2015, with the highest overall number of new infections among those in their twenties largely resulting from IDU [58]. Hepatitis $C$ poses an immense threat to PWID as approximately 50\% of PWID are $\mathrm{HCV}$-antibody positive [59]. According to the American Association for the Study of Liver Diseases and the Infectious Diseases Society of America (AASLD/IDSA) guidelines, the first few years after an individual begins to inject drugs are a high-risk period during which the incidence of contracting HCV can exceed 40\% [36]. In fact, the CDC reported that $64 \%$ of acute HCV infections were in PWID in 2015 [32]. In the absence of a vaccine, the AASLD/IDSA guidelines recommend HCV screening combined with antiviral treatment and other care services (e.g., SUD treatment and needle exchange program) as a potential strategy to decrease the incidence of HCV infection [36]. Recommendations by AASLD/IDSA for the screening and treatment of HCV infection in PWID are summarized in Table 6. In general, all individuals who currently or previously engaged in IDU should be tested for HCV infection. If an HCV antibody test is positive, it should be confirmed by HCV-RNA testing.

There are seven HCV genotypes, of which genotype 1 is the most common in the USA. However, one study found that HCV genotypes 3 and 4 were more significantly prevalent among HIV/HCV co-infected patients in Serbia [60]. Current direct-acting antiviral (DAA) treatment recommendations from the AASLD/ IDSA for treatment-naïve genotype 1 and $3 \mathrm{HCV}$ infections are simplified in Table 7.

Concerns exist among healthcare providers that PWID may fail treatment because of nonadherence and dropout in real-world settings. However, a recent study in the USA found that overall rates of sustained virologic response (SVR) were similar between patients who were active drug users or receiving MAT (96\% of 46) versus those who were not (95\% of 43) [61]. To improve adherence, the PREVAIL study evaluated three models of HCV treatment, comparing 150 patients on MAT with directly observed treatment, group medical visit treatment in which subjects attended weekly treatment, and treatment as usual, in which patients took their own medication [62]. The study suggested that patients in the directly observed and group treatment arms achieved a higher SVR at 12 weeks than in the treatment as usual. SVRs for directly observed treatment, group medical visit, and treatment as usual were 98\%, 93\%, and $89 \%$, although this was not statistically significant $(p=0.19)$ [62]. 
Table 7 Antiviral treatment recommendations for HCV infection by genotype [36]

\begin{tabular}{|c|c|c|c|}
\hline Genotype & Cirrhosis & Agent $^{a}$ & $\begin{array}{l}\text { Duration } \\
\text { (weeks) }\end{array}$ \\
\hline \multirow[t]{5}{*}{$\overline{1 \mathrm{a}}$} & \multirow[t]{4}{*}{ With or without compensated cirrhosis } & Elbasvir/grazoprevir ${ }^{\mathrm{b}}$ & 12 \\
\hline & & Glecaprevir/pibrentasvir $^{\mathrm{b}}$ & 8 \\
\hline & & Ledipasvir/sofosbuvir $^{\mathrm{b}}$ & 12 \\
\hline & & Sofosbuvir/velpatasvir ${ }^{\mathrm{b}}$ & 12 \\
\hline & Without cirrhosis & $\begin{array}{l}\text { Ledipasvir/sofosbuvir if } \mathrm{HIV} \text {-uninfected and } \mathrm{HCV} \\
\mathrm{RNA}<6 \text { million } \mathrm{IU} / \mathrm{mL}^{\mathrm{b}}\end{array}$ & 8 \\
\hline \multirow[t]{5}{*}{$1 \mathrm{~b}$} & \multirow[t]{4}{*}{ With or without compensated cirrhosis } & Elbasvir/grazoprevir ${ }^{\mathrm{b}}$ & 12 \\
\hline & & Glecaprevir/pibrentasvir $^{\mathrm{b}}$ & 8 \\
\hline & & Ledipasvir/sofosbuvir ${ }^{\mathrm{b}}$ & 12 \\
\hline & & Sofosbuvir/velpatasvir ${ }^{\mathrm{b}}$ & 12 \\
\hline & Without cirrhosis & $\begin{array}{l}\text { Ledipasvir/sofosbuvir if HIV-uninfected and } \mathrm{HCV} \\
\text { RNA }<6 \text { million } \mathrm{IU} / \mathrm{mL}^{\mathrm{b}}\end{array}$ & 8 \\
\hline \multirow[t]{6}{*}{3} & Without cirrhosis & Glecaprevir/pibrentasvir $^{\mathrm{b}}$ & 8 \\
\hline & Compensated cirrhosis & Glecaprevir/pibrentasvir $^{\mathrm{b}}$ & 12 \\
\hline & $\begin{array}{l}\text { With or without compensated cirrhosis } \\
\text { without } \mathrm{Y} 93 \mathrm{H} \text { mutation }\end{array}$ & Sofosbuvir/velpatasvir ${ }^{\mathrm{b}}$ & 12 \\
\hline & $\begin{array}{l}\text { With compensated cirrhosis and } \mathrm{Y} 93 \mathrm{H} \\
\text { mutation }\end{array}$ & Sofosbuvir/velpatasvir/voxilaprevir & 12 \\
\hline & No cirrhosis & Daclatasvir + sofosbuvir & 12 \\
\hline & Compensated cirrhosis & Daclatasvir + sofosbuvir \pm ribavirin & 24 \\
\hline
\end{tabular}

${ }^{a}$ All are single-tablet regimens dosed once daily

b Denotes preferred regimen

\section{BACTERIAL INFECTIONS}

Like viral infections, bacterial infections can also be easily transmitted and acquired through IDU. The CDC and HHS reported that IDUs are 16.3 times more likely to develop invasive methicillin-resistant Staphylococcus aureus (MRSA) infections than non-IDU [63]. Among the IDU population, MRSA infections have increased from $4.1 \%$ in 2011 to $9.2 \%$ in 2016 [63]. Risk factors that increase the likelihood of spreading and acquiring bacterial infections are similar to viral infections and include contamination of injectable drugs, drug injection paraphernalia, reuse of needles for injection, and non-sterile injection sites. Common bacterial infections in this population consist of local (e.g., cellulitis or skin abscesses) and systemic infections (e.g., infective endocarditis or osteomyelitis) [63].

\section{Skin and Soft Tissue Infections}

Skin and soft tissue infections (SSTIs) are common in the IDU population as a result of the nature of injection that disrupts the dermis and thus SSTIs are the most common cause of hospital admission for PWID [64]. This is not surprising, given that an important risk factor is the disruption of the skin, which is the major 
Table 8 Antimicrobial therapy for skin and soft tissue infections caused by methicillin-resistant Staphylococcus aureus [38]

\begin{tabular}{|c|c|c|}
\hline Antimicrobial & Dose & Comment \\
\hline Vancomycin & $\begin{array}{l}\text { Target trough concentrations } \\
\text { of } 10-15 \mathrm{mg} / \mathrm{L}^{\mathrm{a}}\end{array}$ & $\begin{array}{l}\text { Parenteral drug of choice for MRSA infections; } \\
\text { alternative for penicillin allergic patients }\end{array}$ \\
\hline Linezolid & $\begin{array}{l}600 \mathrm{mg} \text { IV BID OR } \\
600 \mathrm{mg} \text { PO BID }\end{array}$ & \\
\hline Clindamycin & $\begin{array}{l}600 \mathrm{mg} \text { IV TID OR } \\
300-450 \mathrm{mg} \text { PO QID }\end{array}$ & Inducible resistance in MRSA \\
\hline Daptomycin & $4 \mathrm{mg} / \mathrm{kg}$ IV q24h & $\begin{array}{l}\text { Monitor creatinine phosphokinase (CPK), possible } \\
\text { myopathy }\end{array}$ \\
\hline Doxycycline $^{b}$ & 100 mg PO BID & Not recommended for age $<8$ years \\
\hline Ceftaroline & $600 \mathrm{mg}$ IV BID & \\
\hline Trimethoprim-sulfamethoxazole ${ }^{\mathrm{b}}$ & $\begin{array}{l}1-2 \text { double strength }(160 / \\
800 \mathrm{mg}) \text { tablets PO BID }\end{array}$ & \\
\hline
\end{tabular}

organ protecting humans from infections. A multivariate analysis identified that the disruption of the cutaneous skin barrier is one of the biggest risk factors for developing cellulitis [65]. However, an accurate assessment of the incidence is challenging given variable presentations and unreporting of SSTIs. Regardless, the incidence of clinically diagnosed SSTIs was estimated at 500 per 10,000 persons per year [66]. A high prevalence of cellulitis and skin abscesses among IDUs was reported in San Francisco in 1997. Notably, 85\% of these 169 IDUs injected heroin, a commonly abused drug contributing to OUD. Other drugs that were abused by these IDUs were methamphetamine and cocaine. Approximately $32 \%$ of IDUs developed an active SSTI (i.e., abscess, cellulitis, or both) and 19 of these IDUs had multiple abscesses. Additionally, 68\% of recruited IDUs reported a past infection consisting of an abscess, and $48 \%$ of these IDUs reported never seeking medical treatment for their abscess. The likelihood of developing cellulitis or abscess did not significantly differ between IDUs of different living statuses (e.g., homelessness), the type of drug injected, or the location of injection [67].

Similarly, a study conducted in Denver also reported a high rate of skin infections (including abscesses) among IDUs. The most common drug of abuse was heroin, reported in $41 \%$ of 51 IDUs. In addition, $55 \%$ of these recruited subjects reported a previous bacterial skin infection directly related to injecting drugs, with an average of 4-6 bacterial skin infections per lifetime. Furthermore, 29\% of IDUs reported an active abscess or abscess within the past year [68]. Lastly, in 2009, 28\% of IDUs in the UK reported an injection-site infection with complications that ranged from uncomplicated cellulitis and local abscesses to necrotizing fasciitis and severe sepsis [69].

The most common pathogens causing cellulitis are beta-hemolytic streptococci. Within this subset of streptococci, Streptococcus pyogenes (group A Streptococcus) is the most common species [70-72]. For skin abscesses, the most common offending pathogen is Staphylococcus aureus, regardless of IDU [73]. These pathogens include both methicillin-susceptible and 
Table 9 Antimicrobial therapy for infective endocarditis [40]

\begin{tabular}{|c|c|c|c|}
\hline Antimicrobial & Dose & $\begin{array}{l}\text { Duration } \\
\text { (weeks) }\end{array}$ & Comments \\
\hline \multicolumn{4}{|c|}{ Right-sided native valve endocarditis } \\
\hline \multicolumn{4}{|l|}{ MSSA } \\
\hline $\begin{array}{l}\text { Nafcillin or } \\
\text { oxacillin }\end{array}$ & $\begin{array}{l}12 \mathrm{~g} / 24 \mathrm{~h} \text { IV divided } \\
\text { into } 4-6 \text { equal doses }\end{array}$ & 2 & $\begin{array}{l}\text { For complicated right-sided IE and for left-sided IE, treatment } \\
\text { duration is } 6 \text { weeks }\end{array}$ \\
\hline Cefazolin & $2 \mathrm{~g}$ IV q8h & 6 & Avoid in beta-lactam allergy \\
\hline \multicolumn{4}{|l|}{ MRSA } \\
\hline Vancomycin & $\begin{array}{l}\text { Target trough } \\
\text { concentrations of } \\
15-20 \mathrm{mg} / \mathrm{L}\end{array}$ & 6 & Alternative if patient has severe beta-lactam allergy \\
\hline Daptomycin & $\geq 8 \mathrm{mg} / \mathrm{kg}$ IV q24h & 6 & Bactericidal, monitor CPK \\
\hline \multicolumn{4}{|c|}{ Right-sided prosthetic valve endocarditis } \\
\hline \multicolumn{4}{|l|}{ MSSA } \\
\hline $\begin{array}{l}\text { Nafcillin or } \\
\text { oxacillin }\end{array}$ & $\begin{array}{l}12 \mathrm{~g} / 24 \mathrm{~h} \text { IV divided } \\
\text { into } 4-6 \text { equal doses }\end{array}$ & $\geq 6$ & $\begin{array}{l}\text { Vancomycin should be used alternatively in patients with severe } \\
\text { beta-lactam allergy; cefazolin may be substituted in patients with }\end{array}$ \\
\hline $\begin{array}{l}\text { Plus } \\
\text { Rifampin }\end{array}$ & $\begin{array}{l}900 \mathrm{mg} \text { IV q24h or } \\
300 \mathrm{mg} \text { PO q } 8 \mathrm{~h}\end{array}$ & $\geq 6$ & non-immediate-type hypersensitivity reactions to penicillin \\
\hline $\begin{array}{l}\text { Plus } \\
\text { Gentamicin }\end{array}$ & $\begin{array}{l}3 \mathrm{mg} / \mathrm{kg} \text { IV q24h or } \\
1 \mathrm{mg} / \mathrm{kg} \mathrm{IV} \mathrm{q} 8 \mathrm{~h}\end{array}$ & 2 & \\
\hline \multicolumn{4}{|l|}{ MRSA } \\
\hline Vancomycin & $\begin{array}{l}\text { Target trough } \\
\text { concentrations of } \\
15-20 \mathrm{mg} / \mathrm{L}\end{array}$ & $\geq 6$ & \\
\hline $\begin{array}{l}\text { Plus } \\
\text { Rifampin }\end{array}$ & $\begin{array}{l}900 \mathrm{mg} \text { IV q24h or } \\
300 \mathrm{mg} \text { PO q8h }\end{array}$ & $\geq 6$ & \\
\hline $\begin{array}{l}\text { Plus } \\
\text { Gentamicin }\end{array}$ & $\begin{array}{l}3 \mathrm{mg} / \mathrm{kg} \text { IV q24h or } \\
1 \mathrm{mg} / \mathrm{kg} \text { IV q } 8 \mathrm{~h}\end{array}$ & 2 & \\
\hline
\end{tabular}

${ }^{a}$ Current national guidelines recommend dosing and monitoring by area under the curve rather than trough concentrations; however, data to firmly recommend for the treatment of infective endocarditis are limited. Refer to complete guidelines for more information

methicillin-resistant Staphylococcus aureus (MSSA and MRSA, respectively). While IDU is a risk factor for MRSA SSTIs, occurrences of MRSA SSTIs have also become common in individuals without established risk factors in various parts of the USA [74]. For the treatment of cellulitis in
IDU patients, the Infectious Diseases Society of America (IDSA) Practice Guidelines for SSTIs recommend the use of an antibiotic that is effective against both MRSA and streptococci. In cases of systemic infection, the use of intravenous antibiotics is warranted. The duration of 
therapy is generally 7 days, but can vary depending on clinical response. Recommended treatment regimens for MRSA are listed in Table 8. For skin abscesses, the IDSA Practice Guidelines for SSTIs recommend incision and drainage as the primary management strategy. The addition of an antibiotic with MRSA coverage should only be an adjunct therapy to incision and drainage if the patient exhibits signs or symptoms of a systemic inflammatory response (temperature $>38^{\circ} \mathrm{C}$ or $<36^{\circ} \mathrm{C}$, respiratory rate $>24$ breaths per minute, heart rate $>90$ beats per minute, or white blood cell count $>12,000$ or $<4000$ cells $/ \mu \mathrm{L}$ ) [38].

\section{Infective Endocarditis}

The incidence of infective endocarditis (IE) in IDUs has increased over the past few years, especially among the younger population. According to the CDC's Multiple Cause-ofDeath database, nationwide hospital admissions due to IE for patients younger than 30 years old who are IDU increased from $11 \%$ in 2008 to 27\% in 2014 [75]. Between 1996 and 2016, there were 55,212 deaths from IE associated with drug abuse (DA). The proportion of drug abuse-associated IE (DA-IE) deaths increased from $9.4 \%$ in 1999 to $18.9 \%$ in 2016 [76]. The proportion of deaths from DA-IE among patients younger than 35 years old exceeded the national average, as DA-IE deaths in this population increased from $12.4 \%$ in 1999 to $37.4 \%$ in 2016 [76]. These results were supported by another study showing the doubling of DA-IE in the USA from $8 \%$ in 2002 to $16.3 \%$ in 2016 , with younger patients more frequently having comorbidities such as HIV, HCV, concomitant alcohol abuse, and liver disease. Rural areas, particularly in the Midwest, seem to carry an increased risk for rates of DA-IE [39]. Additionally, hospitalizations due to DA-IE in North Carolina increased significantly from $14 \%$ in 2009 to $56 \%$ in 2014 . While there was no difference in mortality, DA-IE hospital lengths of stay were longer in IDUs than non-IDUs (26 days vs 12 days) [77].

IDUs are at highest risk of developing rightsided IE, as approximately $90 \%$ of right-sided IE patients are IDUs [78]. The most common pathogen causing right-sided IE is $S$. aureus (including MRSA), which accounts for about 70\% of cases and then followed by streptococci and enterococci [79]. Uncommon pathogens that cause right-sided IE are fungi and Gram-negative bacilli (including Pseudomonas aeruginosa) $[80,81]$. Recommended treatment by the American Heart Association (AHA) guidelines for native valve endocarditis (NVE) and prosthetic valve endocarditis (PVE) caused by $S$. $a u$ reus are outlined in Table 9 [40]. While the addition of gentamicin has traditionally been a part of standard therapy for right-sided IE, there is emerging evidence suggesting that it may not be necessary for uncomplicated right-sided IE. Specifically, the addition of gentamicin to cloxacillin 2-week therapy did not provide any therapeutic advantage; cloxacillin monotherapy was as effective as combination therapy [82]. Furthermore, the addition of gentamicin in patients with native valve endocarditis caused by $S$.aureus was associated with nephrotoxicity [83].

\section{Osteomyelitis}

Osteomyelitis is a bone infection that results from hematogenous or contiguous bacterial seeding into the bone. The most common bacteria responsible for osteomyelitis are S. aureus [84]. Osteomyelitis has multiple risk factors, including IDU. Like DA-IE, osteomyelitis in IDU occurs more often in younger individuals. One study conducted in West Florida retrospectively evaluated 2150 individuals with osteomyelitis and reported that those with opioid drug abuse were significantly younger by an average of 11.5 years and had significantly longer hospitalizations by an average 5 days longer than those with diabetes. This may be partly due to lack of central catheter lines among IDUs in the outpatient setting, which would require these individuals to stay in the hospital longer. Diabetic patients may also require amputations depending on comorbidities (such as peripheral artery disease), which may contribute to shorter hospitalizations as well. However, regardless of the rationale, osteomyelitis among IDUs has 
been associated with younger age and shown to increase healthcare costs when compared to individuals with other common risk factors [85].

Although IDU is a well-documented risk factor for osteomyelitis, there is limited information on treatment recommendation for IDUrelated osteomyelitis. When empiric therapy is warranted for suspected osteomyelitis, regimens should provide coverage for MRSA, streptococci, and Gram-negative bacilli. The IDSA Clinical Practice Guideline for Native Vertebral Osteomyelitis recommends an initial regimen of vancomycin (target trough concentration $15-20 \mathrm{mg} / \mathrm{L}$ ) plus a 3rd or 4th generation cephalosporin. In the case of allergy or intolerance, alternative therapies may include a combination of daptomycin or fluoroquinolone. However, in patients with normal neurologic function and stable hemodynamics, it is recommended to hold antibiotic therapy until a pathogen is isolated for directed antimicrobial therapy [43].

\section{CONCLUSION}

All healthcare providers play a vital role in identifying substance abuse and OUD. Early identification is critical as the implications of long-term opioid and substance abuse are serious, potentially life-threatening. The implications include a myriad of other health complications, such as viral infections, bacterial infections, overdose, and death. Guidelines from HHS HIV/AIDS also endorse focusing on early signs of OUD and the use of MAT to prevent the spread of infection and reduce the risks of morbidity and mortality that are associated with opioid use.

For the infectious diseases community, provider training for early detection of OUD and antimicrobial stewardship can increase awareness in the community and provide PWID adequate social support and harm reduction resources. As infectious diseases providers are often a point of contact for patients hospitalized for these infections, they play a unique role by screening for OUD, initiating MAT, and facilitating linkage to ID and OUD management after hospital discharge [86]. As such, obtaining a thorough history and background on patients to recognize the potential of opioid use as the underlying cause is a simple yet important step in combating the opioid epidemic. In addition, community resources such as expansion of clean sterile needles, safe injection spaces, and OUD education are critical to inform community members to prevent the spread of associated infections. As healthcare providers, future research is needed to identify neurochemical and psychosocial factors leading to OUD as well as reinforcement of antimicrobial stewardship and education on antibiotic resistance in the setting of IDU.

\section{ACKNOWLEDGEMENTS}

Funding. No funding or sponsorship was received for this study or publication of this article.

Authorship. All named authors meet the International Committee of Medical Journal Editors (ICMJE) criteria for authorship for this article, take responsibility for the integrity of the work as a whole, and have given their approval for this version to be published.

Disclosure. Jessica F. Jones, Jamie Legaspi, Eric Chen, Kelly Lee, and Jennifer Le declare that they have no conflict of interest.

Compliance with Ethics Guidelines. This article is based on previously conducted studies and does not contain any studies with human participants or animals performed by any of the authors.

Open Access. This article is licensed under a Creative Commons Attribution-NonCommercial 4.0 International License, which permits any non-commercial use, sharing, adaptation, distribution and reproduction in any medium or format, as long as you give appropriate credit to the original author(s) and the source, provide a link to the Creative Commons licence, and indicate if changes were made. The images or 
other third party material in this article are included in the article's Creative Commons licence, unless indicated otherwise in a credit line to the material. If material is not included in the article's Creative Commons licence and your intended use is not permitted by statutory regulation or exceeds the permitted use, you will need to obtain permission directly from the copyright holder. To view a copy of this licence, visit http://creativecommons.org/licenses/by$\mathrm{nc} / 4.0 /$.

\section{REFERENCES}

1. Guy GP, Jr, Zhang K, Bohm MK, et al. Vital signs: changes in opioid prescribing in the United States, 2006-2015. MMWR Morb Mortal Wkly Rep. 2017;66(26) https://www.cdc.gov/mmwr/ volumes $/ 66 / \mathrm{wr} / \mathrm{mm} 6626 \mathrm{a} 4 . \mathrm{htm} ? \mathrm{~s}$ _cid= mm6626a4_w.

2. Florence CS, Zhou C, Luo F, Xu L. The economic burden of prescription opioid overdose, abuse, and dependence in the United States, 2013. Med Care. 2016;54:901-6.

3. Wide-ranging online data for epidemiologic research (WONDER). Atlanta, GA: CDC, National Center for Health Statistics; 2020. https://wonder. cdc.gov.

4. Saxon AJ. The unmet challenges of co-occurring alcohol and opioid use. Alcohol Clin Exp Res. 2018. https://doi.org/10.1111/acer.13797.

5. Kosten TR, George TP. The neurobiology of opioid dependence: implications for treatment. Sci Pract Perspect. 2002;1(1):13-20. https://doi.org/10.1151/ spp021113.

6. Hedegaard H, Miniño AM, Warner M. Drug overdose deaths in the United States, 1999-2018.pdf icon NCHS Data Brief, no 356. Hyattsville, MD: National Center for Health Statistics. 2020.

7. Centers for Disease Control and Prevention (CDC). Vital signs: overdoses of prescription opioid pain relievers-United States, 1999-2008. MMWR MorbMortal Wkly Rep. 2011;60(43):1487-92.

8. Rudd RA, Paulozzi LJ, Bauer MJ, et al. Increases in heroin overdose deaths-28 states, 2010 to 2012. MMWR MorbMortal Wkly Rep. 2014;63(39):849.

9. Gladden RM, Martinez P, Seth P. Fentanyl law enforcement submissions and increases in synthetic opioid-involved overdose deaths-27 states, 2013-2014. MMWR MorbMortal Wkly Rep. 2016;65:837-43.

10. O'Donnell JK, Gladden RM, Seth P. Trends in deaths involving heroin and synthetic opioids excluding methadone, and law enforcement drug product reports, by census region-United States, 2006-2015. MMWR MorbMortal Wkly Rep. 2017;66:897-903.

11. O’Donnell JK, Halpin J, Mattson CL, Goldberger BA, Gladden RM. Deaths involving fentanyl, fentanyl analogs, and U-47700-10 states, July-December 2016. MMWR Morb Mortal Wkly Rep. 2017;66: 1197-202.

12. Vardanyan RS, Hruby VJ. Fentanyl-related compounds and derivatives: current status and future prospects for pharmaceutical applications. Future Med Chem. 2014;6(4):385-412. https://doi.org/10. 4155/fmc.13.215.

13. Drug Enforcement Administration. 2019 National Drug Threat Assessment. Drug Enforcement Administration Strategic Intelligence Section, U.S. Department of Justice. Published December 2019. https://www.dea.gov/sites/default/files/2020-01/ 2019-NDTA-final-01-14-2020_Low_Web-DIR-00720_2019.pdf. Accessed March 17, 2020

14. SAMHSA, 2011. Results from the 2010 National Survey on Drug Use and Health: Summary of National Findings. NSDUH Series H-41, HHS Publication No. (SMA) 11-4658, Rockville, MD.

15. Wilson N, Kariisa M, Seth P, et al. Drug and opioidinvolved overdose deaths-United States, 2017-2018. MMWR Morb Mortal Wkly Rep. 2020;69:290-7.

16. Lankenau SE, Teti M, Silva K, Jackson BJ, Harocopos A, Treese M. Initiation into prescription opioid misuse amongst young injection drug users. Int J Drug Policy. 2012;23:37-44.

17. Jones CM. Heroin use and heroin use risk behaviors among nonmedical users of prescription opioid pain relievers-United States, 2002-2004 and 2008-2010. Drug Alcohol Depend. 2013;132(1-2): 95-100.

18. Compton WM, Jones CM, Baldwin GT. Relationship between nonmedical prescription-opioid use and heroin use. N Engl J Med. 2016;374(2):154-63. https://doi.org/10.1056/NEJMra1508490.

19. Peavy KM, Banta-Green CJ, Kingston S, Hanrahan M, Merrill JO, Coffin PO. "Hooked on" prescriptiontype opiates prior to using heroin: results from a survey of exchange clients. J Psychoactive Drugs. 2012;44:259-65. 
20. Lyden J, Binswanger IA. The United States opioid epidemic. Semin Perinatol. 2019. https://doi.org/ 10.1053/j.semperi.2019.01.001.

21. Wiese AD, Griffin MR, Schaffner W, et al. Longacting opioid use and the risk of serious infections: a retrospective cohort study. Clin Infect Dis. 2018. https://doi.org/10.1093/cid/ciy809.

22. Schranz AJ, Barrett J, Hurt CB, Malvestutto C, Miller WC. Challenges facing a rural opioid epidemic: treatment and prevention of HIV and hepatitis C. Curr HIV/AIDS Rep. 2018;15:245-54.

23. Krupitsky E, Nunes EV, Ling W, Illeperuma A, Gastfriend DR, Silverman BL. Injectable extendedrelease naltrexone for opioid dependence: a doubleblind, placebo-controlled, multicentre randomised trial. Lancet. 2011;377(9776):1506-13. https://doi. org/10.1016/S0140-6736(11)60358-9.

24. Gibson AE, Degenhardt LJ. Mortality related to pharmacotherapies for opioid dependence: a comparative analysis of coronial records. Drug Alcohol Rev. 2007;26(4):405-10. https://doi.org/10.1080/ 09595230701373834.

25. Low AJ, Mburu G, Welton NJ, et al. Impact of opioid substitution therapy on antiretroviral therapy outcomes: a systematic review and meta-analysis. Clin Infect Dis. 2016;63(8):1094-104. https://doi. org/10.1093/cid/ciw416.

26. Des Jarlais DC, Perlis T, Arasteh K, et al. Reductions in hepatitis $\mathrm{C}$ virus and HIV infections among injecting drug users in New York City, 1990-2001. AIDS. 2005;19(Suppl 3):S20-S2525. https://doi.org/ 10.1097/01.aids.0000192066.86410.8c.

27. Winstanley EL, Stover AN. The impact of the opioid epidemic on children and adolescents. Clin Ther. 2019;41(9):1655-62. https://doi.org/10.1016/j. clinthera.2019.06.003.

28. Panel on Antiretroviral Guidelines for Adults and Adolescents. Guidelines for the Use of Antiretroviral Agents in Adults and Adolescents with HIV. Department of Health and Human Services. https:// www.aidsinfo.nih.gov/ContentFiles/ AdultandAdolescentGL.pdf. Accessed March 28, 2020

29. HIV: Statistics overview. Atlanta, GA: Centers for Disease Control and Prevention; November 21, 2019. www.cdc.gov/hiv/statistics/overview/index. html. Accessed March 28, 2020

30. Kipke MD, Weiss G, Wong CF. Residential status as a risk factor for drug use and HIV risk among young men who have sex with men. AIDS Behav. 2007;11(6 Suppl):56-69. https://doi.org/10.1007/ s10461-006-9204-5.
31. Crooks D, Tsui J, Anderson B, et al. Differential risk factors for HIV drug and sex risk-taking among nontreatment-seeking hospitalized injection drug users. AIDS Behav. 2015;19(3):405-11. https://doi.org/10. 1007/s10461-014-0754-7.

32. Viral hepatitis surveillance-United States, 2015. Atalnta, GA: Centers for Disease Control and Prevention; November 2016. www.cdc.gov/hiv/pdf/ library/reports/surveillance/cdc-hiv-surveillancereport-2015-vol-27.pdf. Accessed April 19, 2020.

33. Hepatitis C Prevalence Estimates 2013-2016. Atlanta, GA: Centers for Disease Control and Prevention; November 6, 2018. www.cdc.gov/ nchhstp/newsroom/2018/hepatitis-c-prevalenceestimates.html. Accessed March 28, 2020

34. Hepatitis C Online. Seattle, WA; University of Washington; July 17, 2018. www.hepatitisc.uw. edu. Accessed March 28, 2020.

35. Schulte $M$, Hser $Y$, Saxon A, et al. Risk factors associated with HCV among opioid-dependent patients in a multisite study. J Community Health. 2015;40(5):940-7. https://doi.org/10.1007/s10900015-0016-2.

36. HCV guidance: recommendations for testing, managing, and treating hepatitis C. www. hcvguidelines.org. HVCGuidelines.org website. Accessed March 28, 2020.

37. Ramakrishnan K, Salinas R, Higuita N, et al. Skin and soft tissue infections. Am Fam Physician. 2015 Sep 15;92(6):474-83.

38. Stevens D, Bisno A, Chambers H, et al. Practice guidelines for the diagnosis and management of skin and soft tissue infections: 2014 update by the Infectious Diseases Society of America. CID. 2014;59(2):e10-52.

39. Kadri A, Wilner B, Hernandez A, et al. Geographic trends, patient characteristics, and outcomes of infective endocarditis associated with drug abuse in the United States from 2002 to 2016. J Am Heart Assoc. 2019;8(19):e012969.

40. Baddour L, Wilson W, Bayer A, et al. Infective endocarditis in adults: diagnosis, antimicrobial therapy, and management of complications. A scientific statement for healthcare professionals from the American Heart Association. AHA. 2015;132: 1435-86.

41. Wald E. Risk factors for osteomyelitis. Am J Med. $1985 ; 78(6 \mathrm{~B}): 206-12$.

42. Hatzenbuehler J, Pulling T. Diagnosis and management of osteomyelitis. Am Fam Physician. 2011;84(9):1027-33. 
43. Berbari E, Kanj S, Kowalski T, et al. 2015 Infectiou Diseases Society of America (IDSA) clinical practice guidelines for the diagnosis and treatment of native vertebral osteomyelitis in adults. Clin Infect Dis. 2015;61(6):e26-46.

44. Schwetz TA, Calder T, Rosenthal E, Kattakuzhy S, Fauci AS. Opioids and infectious diseases: a converging public health crisis. $J$ Infect Dis. 2019;220(3):346-9. https://doi.org/10.1093/infdis/ jiz133.

45. Zule WA, Oramasionwu C, Evon D, et al. Eventlevel analyses of sex-risk and injection-risk behaviors among nonmedical prescription opioid users. Am J Drug Alcohol Abuse. 2016;42(6):689-97. https://doi.org/10.1080/00952990.2016.1174706.

46. HIV and people who inject drugs. Atlanta, GA: Centers for Disease Control and Prevention; February 6,2020. www.cdc.gov/hiv/group/hiv-idu. html. Accessed March 28, 2020

47. Hoots BE, Finlayson TJ, Broz D, Paz-Bailey G. Antiretroviral therapy use among HIV-infected people who inject drugs-20 cities, United States, 2009-2015. J Acquir Immune Defic Syndr. 1999;2017(75 Suppl 3):S392-S396396.

48. Griffith DC, Farmer C, Gebo KA, et al. Uptake and virological outcomes of single- versus multi-tablet antiretroviral regimens among treatment-naïve youth in the HIV Research Network. HIV Med. 2019;20(2):169-74. https://doi.org/10.1111/hiv. 12695.

49. Williams EC, Joo YS, Lipira L, Glass JE. Psychosocial stressors and alcohol use, severity, and treatment receipt across human immunodeficiency virus (HIV) status in a nationally representative sample of US residents. Subst Abus. 2017;38(3):269-77.

50. Crane HM, McCaul ME, Chander G, et al. Prevalence and factors associated with hazardous alcohol use among persons living with HIV across the US in the current era of antiretroviral treatment. AIDS Behav. 2017;21(7):1914-25.

51. Scott-Sheldon LAJ, Carey KB, Johnson BT, Carey MP, MASH Research Team. behavioral interventions targeting alcohol use among people living with HIV/AIDS: a systematic review and metaanalysis. AIDS Behav. 2017;21(Suppl 2):126-43. https://doi.org/10.1007/s10461-017-1886-3.

52. Helleberg M, May MT, Ingle SM, et al. Smoking and life expectancy among HIV-infected individuals on antiretroviral therapy in Europe and North America. AIDS. 2015;29(2):221-9.

53. Lesko CR, Tong W, Moore RD, Lau B. Retention, antiretroviral therapy use and viral suppression by history of injection drug use among HIV-infected patients in an urban HIV clinical cohort. AIDS Behav. 2017;21(4):1016-24. https://doi.org/10. 1007/s10461-016-1585-5.

54. Fernandes RM, Cary M, Duarte G, et al. Effectiveness of needle and syringe programmes in people who inject drugs-an overview of systematic reviews. BMC Public Health. 2017;17(1):309. https://doi.org/10.1186/s12889-017-4210-2.

55. Syringe Services Programs (SSPs). Atlanta, GA: Centers for Disease Control and Prevention; May 23, 2019. https://www.cdc.gov/ssp/syringe-servicesprograms-faq.html

56. Des Jarlais DC, et al. HIV incidence among injection drug users in New York City, 1990 to 2002: use of serologic test algorithm to assess expansion of HIV prevention services. Am J Public Health. 2005;95(8):1439-44.

57. Des Jarlais DC, et al. Reductions in hepatitis $C$ virus and HIV infections among injecting drug users in New York City, 1990-2001. Aids. 2005;19: S20-S2525.

58. New hepatitis $C$ infections nearly tripled over five years [press release]. Atlanta, GA: Centers for Disease Control and Prevention; May 11, 2017. www. cdc.gov/media/releases/2017/p-hepatitis-cinfections-tripled.html. Accessed March 28, 2020.

59. Degenhardt L, Peacock A, Colledge S, et al. Global prevalence of injecting drug use and sociodemographic characteristics and prevalence of HIV, HBV, and HCV in people who inject drugs: a multistage systematic review [published correction appears in Lancet Glob Health. 2017 Nov 15]. Lancet Glob Health. 2017;5(12):e1192-e1207207. https://doi. org/10.1016/S2214-109X(17)30375-3.

60. Salemovic D, Pesic-Pavlovic I, Jevtovic D, et al. Intravenous drug use-an independent predictor for HCV genotypes 3 and 4 infection among HIV/ HCV co-infected patients. Arch Med Sci. 2017;13(3):652-8. https://doi.org/10.5114/aoms. 2017.66022 .

61. Norton BL, Fleming J, Bachhuber MA, et al. High $\mathrm{HCV}$ cure rates for people who use drugs treated with direct acting antiviral therapy at an urban primary care clinic. Int J Drug Policy. 2017;47: 196-201. https://doi.org/10.1016/j.drugpo.2017. 07.021 .

62. Litwin AH, Agyemang L, Akiyama $M$, et al. The PREVAIL Study: intensive models of HCV care for people who inject drugs. J Hepatol. 2017;66:S72. https://doi.org/10.1016/S0168-8278(17)30406-3. 
63. Jackson $\mathrm{K}$, Bohm $\mathrm{M}$, Brooks $\mathrm{J}$, et al. Invasive methicillin-resistant Staphylococcus aureus infections among persons who inject drugs-six sites, 2005-2016. MMWR. 2018;67(22):625-8.

64. Ebright J, Pieper B. Skin and soft tissue infections in injection drug users. Infect Dis Clin North Am. 2002;16(3):697-712.

65. Dupuy A, Benchikhi H, Roujeau J, et al. Risk factors for erysipelas of the leg (cellulitis): case-control study. BMJ. 1999;318(7198):1591-4.

66. Ray G, Suaya J, Baxter R. Incidence, microbiology, and patient characteristics of skin and soft-tissue infections in a US population: a retrospective population-based study. BMC Infect Dis. 2013;13: 252.

67. Binswanger I, Kral A, Bluthenthal R, et al. High prevalence of abscesses and cellulitis among community-recruited injection drug users in San Francisco. Clin Infect Dis. 2000;30(3):579-81.

68. Phillips K, Stein M. Risk practices associated with bacterial infections among injection drug users in Denver, CO. Am J Drug Alcohol Abuse. 2010;36(2): 92-7.

69. Lavender T, McCarron B. Acute infections in intravenous drug users. Clin Med. 2013;13:511-3.

70. Raff AB, Kroshinsky D. Cellulitis: a review. JAMA. 2016;316(3):325-37.

71. Bernard P, Bedane C, Denis F, et al. Streptococcal cause of erysipelas and cellulitis in adults. A microbiologic study using a direct immunofluorescence technique. Arch Dermatol. 1989;125(6):779.

72. Jeng A, Beheshti M, Li J, et al. The role of betahemolytic streptococci in causing diffuse, nonculturable cellulitis: a prospective investigation. Medicine (Baltimore). 2010;89(4):217.

73. Summanen P, Talan D, Strong C, et al. Bacteriology of skin and soft-tissue infections: comparison of infections in intravenous drug users and individuals with no history of intravenous drug use. Clin Infect Dis. 1995;20(suppl 2):S279.

74. Moran G, Krishnadasan A, Gorwitz R, et al. Methicillin-resistant $S$. aureus infections among patients in the emergency department. $\mathrm{N}$ Engl J Med. 2006;355(7):666.
75. Deo S, Raza S, Kalra A, et al. Admissions for infective endocarditis in intravenous drug users. J Am Coll Cardiol. 2018;71(14):1596-7.

76. Njoroge L, Al-Kindi S, Koromia G, et al. Changes in the association of rising infective endocarditis with mortality in people who inject drugs. JAMA Cardiol. 2018;3(8):779-80.

77. Hartman L, Barnes E, Bachmann L, et al. Opiate injection-associated infective endocarditis in the Southeastern United States. Am J Med Sci. 2016;32(6):603-8.

78. Moreillon P, Que Y. Infective endocarditis. Lancet. 2004;363(9403):139.

79. Matthew J, Addai T, Anand A, et al. Clinical features, site of involvement, bacteriologic findings, and outcomes of infective endocarditis in intravenous drug users. Arch Intern Med. 1995;155(15):1641.

80. Bisbe J, Miro J, Moreno A, et al. Disseminated candidiasis in addict who use brown heroin: report of 83 cases and review. Clin Infect Dis. 1992;15(6):910.

81. Shekar R, Rice T, Zierdt C, et al. Outbreak of endocarditis caused by Pseudomonas aeruginosa serotype O11 among pentazocine and tripelennamine abusers in Chicago. J Infect Dis. 1985;151(2):203.

82. Ribera E, Jimenez J, Cortes E, et al. Effectiveness of cloxacillin with and without gentamicin in shortterm therapy for right-sided Staphylococcus aureus endocarditis. A randomized controlled trial. Ann Intern Med. 1996;125(12):969-74.

83. Cosgrove S, Vigliani G, Fowler V, et al. Initial lowdose gentamicin for Staphylococcus aureus bacteremia and endocarditis is nephrotoxic. Clin Infect Dis. 2009;48:713-21.

84. Sia I, Berbari E. Osteomyelitis. Best Practice Res Clin Rheumatol. 2006;20(6):1065-81.

85. Yuschak E, Chase S, Haq F, et al. Demographics and length of stay for osteomyelitis in opioid drug users: a unique population with high healthcare costs. Cureus. 2019;11(3):e4339.

86. Seval N, Eaton E, Springer SA. Beyond antibiotics: a practical guide for the infectious disease physician to treat opioid use disorder in the setting of associated infectious diseases. Open Forum Infect Dis. 2019;7(1):ofz539. 